больного удалось спасти, а так бы врач оказался за решёткой. Эти два происшествия ярко отражают важность этики и деонтологии в здравоохранении.

Обсуждение. Участившиеся случаи искажения кинорежиссерами в кинофильмах отношения медработников между собою, негативно отражается на отношении населения к ним. Складывается впечатление, что они, игнорируя мораль, ведут себя предельно вульгарно. Что они заняты не лечением пациентов, а интимной близостью друг с другом. Это клевета, так как эти надуманные киносюжеты совершенно не отражают истинного отношения между медработниками. В этом я убедился за 60 лет работы в здравоохранении. Воспитание студентов-медиков начинается с первого курса. Они досконально изучают этику и деонтологию, чтобы в дальнейшем свято их соблюдать во врачебной деятельности. Во время работы случаются совсем другие проблемы, о которых упоминалось в этой статье. Они сугубо медицинские и никакого отношения к интиму не имеют. В них отражены истинные медицинские проблемы по этике и деонтологии. В одном, врач допустил ошибку в дозе препарата, а в другом медсестра поленилась перепроверить пробу крови на совместимость. Весь образ жизни и врача, и медицинской сестры направлен на спасение пациента. И приписывать им в это время любовные отношения, просто предел цинизма, да это просто невозможно - какая любовь, если на глазах умирает человек! Таким образом, в этих двух наблюдениях из медицинской практики ярко представлена истинная сущность медицинской этики и деонтологии, Если кинорежиссеры сочтут для себя удобным, то они могут их применить в сценической деятельности.

Заключение. Кинорежиссерам необходимо более сдержано относится к сюжетам, в которых представлены сексуальные сцены с участием медицинских работников. Ведь такая кинолента усиливает необоснованные нападки населения на работников здравоохранения и может привести к криминальным последствиям. Следует помнить о том, что полученные врачами и медицинскими сестрами знания по этике и деонтологии и позволяют им быть такими, какими их представляют в кино. У них много своих профессиональных проблем, о двух из которых написано в статья. У медработников надо беречь нервную систему и не пиарится на выдуманных сюжетах.

$$
* * *
$$

1. Зеленкова И.Л. Беляева Е.В. Этика: Учебное пособие. Мн. Изд. 1995

2. $\quad$ Этический Кодекс Медицинской сестры России (Российская Ассоциация медицинских сестер). 1997

3. Сергеев Ю.Д. Медицинское право. Учебный комплекс в 3 томах. М.: ГЭОТАР-МЕДИА. 2008.777 с.

4. Двойников С.И. Аббясов И.Х. Уход за больными терапевтического и хирургического профиля. Учебное пособие. Самара. 2011.- 196 с.

5. Шапошников В.И. Современные проблемы медицинского образования. Издательство Palmarium publishing, ISBN^ 978 -3-659-98368-9, 2013, 47c.

6. Рамонова Л.П., Шапошников В.И.. Бондаренко П.П. «Сестринское дело в хирургии» Учебное пособие Курс лекций для студентов факультета высшего профессионального образования (квалификация бакалавр). Краснодар, 2013, 167c.

\title{
Klycheva O.I., Jinzala L. \\ Comparative analysis of the frequency of indications for cesarean section in India and Russia
}

Kursk State Medical University

(Russia, Kursk)

doi: $10.18411 / \mathrm{j}-10-2018-161$

idsp: 000001:lj-10-2018-161

The incidence of cesarean section is steadily rising. During the last decade there has been two-to-three fold rise in the incidence from the initial rate of about $10 \%$. Current rate is about 15\%. Apart from increased safety of the operation due to improved anesthesia, availability of blood transfusion and antibiotics, the other factors for rising cesarean section 
rate: rising incidence of primary cesarean delivery; identification of at risk fetuses before term; identification of high-risk pregnancy; wider use of repeat cesarean section; rising rates of induction of labor and failure of induction; decline in operative vaginal (midforceps, vacuum); delivery and manipulative vaginal delivery (rotational forceps); decline in vaginal breech delivery; increased number of women with age $>30$ years and associated medical complications.

Absolute causes of caesarean section in India and frequency of indications of cesarean section. Primigravidae: fetal distress 19,1\%; cephalopelvic disproportion (CPD) 13,5\%; dystocia (dysfunctional labor ) nonprogress of labor 4,5\%; malposition and malpresentation (occipitoposterior, breech) 11,5\%. Mutigravidae: previous cesarean delivery therapy 11\%; antepartum hemorrhage (placenta previa, placental abruption 7,2\%; malpresentation (breech, transverse lie) $8,5 \%$; central placenta previa 5,5\%; contracted pelvis or cephalopelvic disproportion absolute $13,5 \%$.

Caesarean section in Russia.

Obligatory indications found in the parturient woman: anatomically narrowed pelvis; early placental abruption in normal location; complete placenta previa; bleeding with incomplete presentation; severe preeclampsia and eclampsia, renal insufficiency; scar tissue of the pelvis, vagina, the walls of the uterus, cervix, tumor neoplasms of the pelvic organs, fistulas of the genital organs and intestines. From the side of the fetus: transverse, oblique, pelvic presentation; incorrect entry of the head into the birth canal; prolapse of the umbilical cord; acute oxygen starvation; death or maternity death.

Relative indications from the mother and fetus. From the side of the pregnant: a clinically narrowed pelvis; gestosis, lasting from the 20th week of pregnancy and poorly treatable; extragenital diseases, which with natural delivery will lead to a significant deterioration in health; weak labor activity, pathological process of the generic process; congenital pathologies of genital organs; postterm pregnancy; age over 30, especially in women giving birth for the first time. From the side of the fetus: a chronic impairment of blood circulation between the fetus and the placenta; early discharge of water in the pelvic presentation.

Frequency comparison of indications for cesarean section between Russia and India. Obstetric and gynecological history: medical abortion 28,6\% / 35,7\%*; spontaneous miscarriage 19,8\% / 26,5\%*; frozen pregnancy $14,7 \% * / 0,5 \%$; ectopic pregnancy rate $6,2 \%$ / $12,5 \% *$. Gynecological anamnesis: erosion of the cervix 8,4\% / 12,5*; myoma of the uterus $6,4 \% / 14,5^{*}$; ovarian cyst 3,6\% / 8,5\%*; infertility 6,8\% / 8,9\%*. Extragenital diseases: anemia $27,4 \%$ / 32,7\%*; chronic pyelonephritis 20,6\%* / 18,5; hypertension 11,7\% / 18,7\%*; diseases of the thyroid gland $10,7 \% / 16,7 \% *$; diseases of the gastrointestinal tract $9,7 \%$ / $12,5 \% *$; diseases of the respiratory system $8,6 \% / 9,6 \% *$; diseases of the cardiovascular system $6,4 \% / 7,4 \% *$; obesity $4,7 \% * / 3,7 \%$. Infectious diseases in history: the carrier of the human papillomavirus and cytomegalovirus virus 32,3\%* / 28,8\%; chlamydia 18,7\% / $22.7 \% *$; ureaplasmosis 10,6\% / 15,6\%*; chronic tonsillitis and chronic bronchitis 7,8\% / $8,6 \% *$. Comparison between Russia and India (* - this symbol indicate higher in percent)

Cesarean section is usually planned in advance. But sometimes there are situations in which emergency intervention is the only way to save the life of the mother and baby. This is an operation for life indications: too large for the pelvis head, the detection of pathology in the process of childbirth; early discharge of amniotic fluid in the absence of labor; weak birth of the uterus even after the stimulation of childbirth; placental abruption during labor; threat of rupture of the uterus or the beginning of a rupture - with such trauma there is a severe 
bleeding; prolapse of umbilical cord loops and blockage by their head; hypoxia of the fetus, threatening its death; preeclampsia of a pregnant woman, and renal failure.

$$
* * *
$$

1. Bernstein, S.N. Trial of labor versus repeat caesarean: are patients making an informed decision? / S.N. Bernstein, S. Matalon-Grazi, B.M. Rosenn // Obstet. Gynecol. - 2012. - Vol. 207, N 3. - P. 1-6.

2. Bharadwaj, M. A four year audit of deliveries by caeserean section at a medical college hospital in Central India / M.A. Bharadwaj, J.N. Modi // J. Reproduct. Contracep. Obstet. Gynecol. - 2017. - Vol. 4, N 6. P.1775-1782.

3. Creating a public agenda for maternity safety and quality in caesarean delivery / E.K. Main [et al.] // Obstet. Gynecol. - 2012. - Vol. 120, N 5. - P. 1194-1198.

4. Palacios-Jaraguemada, M. Caesarean section in cases of placenta previa and accrete / M. Palacios-Jaraguemada // Best Pract. Res. Clin. Obstet. Gynecol. - 2013. - Vol. 27, N 2. - P. 221-232.

5. The birthing review project / T. Budhwa [et al.] // A Report by the Child Health for the Greater Toronto Area. April 2010. $-60 \mathrm{p}$.

6. The global numbers and costs of additionally needed and unnecessary caesarean section performed per year: overuse as a barrier to universal coverage / L. Gibbons [et al.] // Word Health Report. - 2010. - 30 p.

7. The rising trend in caesarean section rates: should we and we reduce it? / M. Goonewardene [et al.] // Sri Lanca J. Obstet. Gynecol. - 2012. - Vol. 34. - P. 11-18. 